\title{
Data report: bio- and lithofacies, mineralogy, and organic content of Challenger Mound (Porcupine Seabight, SW Ireland)'
}

\author{
Philippe Léonide, ${ }^{2}$ Marc Floquet, ${ }^{2}$ and François Baudin ${ }^{3}$
}

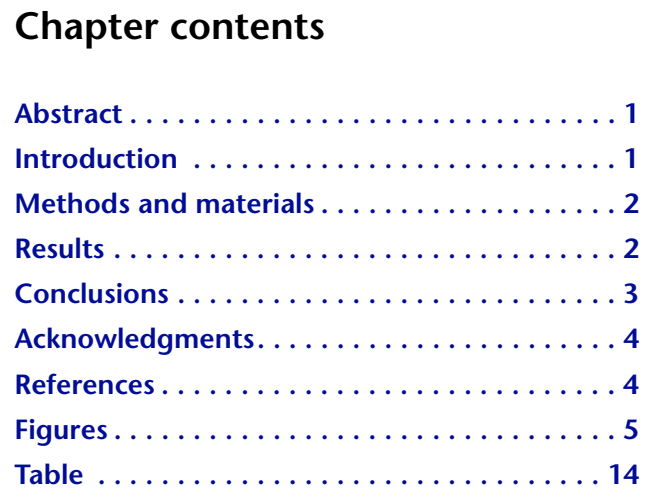

${ }^{1}$ Léonide, P., Floquet, M., and Baudin, F., 2009. Data report: bio- and lithofacies, mineralogy, and organic content of Challenger Mound (Porcupine Seabight, SW Ireland). In Ferdelman, T.G., Kano, A., Williams, T., Henriet, J.-P., and the Expedition 307 Scientists, Proc. IODP, 307: Washington, DC (Integrated Ocean Drilling Program Management International, Inc.).

doi:10.2204/iodp.proc.307.204.2009

${ }^{2}$ Laboratoire de Géologie des Systèmes et des Réservoirs Carbonatés, Université de Provence, EA 4234 Marseille, France. Correspondence author: Philippe.Leonide@univ-provence.fr ${ }^{3}$ UMR CNRS 7072 Tectonique, Université Pierre et Marie Curie-Paris 6, Paris, France.

\begin{abstract}
Sedimentologic, mineralogic, and geochemical analyses were performed on samples from Hole U1317A drilled on Challenger Mound during Integrated Ocean Drilling Program Expedition 307. Challenger Mound consists entirely of sediments bearing well-preserved coldwater coral Lophelia pertusa and other various bioclasts (planktonic foraminifers, cocolithophorids, echinoderms, sponge spicules, etc.) and containing large amounts of clays and quartz. Bioerosion of corals played an important role in generating carbonate grains. The biogenic fraction is autochthonous, whereas the siliciclastic fraction (dominated by illite and kaolinite-chlorite) is clearly allochthonous. Organic matter content is low, and no organic matter of bacterial origin was recognized. Challenger Mound is composed of a mixture of skeletal and siliciclastic components.
\end{abstract}

\section{Introduction}

During Integrated Ocean Drilling Program Expedition 307, Challenger Mound $\left(51^{\circ} 22.8^{\prime} \mathrm{N}, 11^{\circ} 43.1^{\prime} \mathrm{W}\right.$; water depth $\left.=781-815 \mathrm{~m}\right)$ (Fig. F1) was drilled to unveil the nature and origin of the deepwater carbonate mounds by clarifying the microbial role in mound construction and assessing whether past geofluid migration events acted as a prime trigger for mound genesis (see the "Expedition 307 summary" chapter). In order to resolve the first assumption, the main objectives of this study were to describe the biologic and lithologic composition (including mineralogy) of the mound and its organic matter content. Challenger Mound developed in the Belgica Mound Province on the eastern slope of Porcupine Seabight (Fig. F1), where 66 conical mounds (single or in elongated clusters) occur at depths from 550 to $1025 \mathrm{~m}$. The mounds are partly enclosed in an impressive set of contourites (Van Rooij et al., 2003). They are as high as $160 \mathrm{~m}$ and rest on a seismically discontinuous surface (De Mol et al., 2002; Huvenne et al., 2003). A coral ecosystem dominated by the coldwater coral Lophelia pertusa covers some mounds, whereas Challenger Mound is topped by dead coral rubble (Foubert et al., 2005). 


\section{Methods and materials}

This study is based on sedimentologic, mineralogic, and geochemical analyses of the sediments from Hole U1317A that cover Challenger Mound (Figs. F1, F2). The facies description is based on optical microscope and environmental scanning electron microscopy (SEM) (XL 30 ESEM, FEI, Eindhoven) investigations on 21 samples that cover the whole range of facies of Challenger Mound. Sample horizons are shown on the columnar section of Hole U1317A (Fig. F2). We used the limestone terminology proposed by Dunham (1962) and later modified by Embry and Klovan (1971), which is appropriate for the sediments drilled during the expedition (see the "Expedition 307 summary" chapter). In order to quantify the sediment compositions, lithologic and biologic components were identified at $\sim 300$ points on a thin section of each sample. Mineral phases were identified by energy dispersive X-ray spectrometry microanalysis (DX4, EDAX, New Jersey) and X-ray diffraction (XRD) (D500, Siemens, CuKo, 40 kV, $30 \mathrm{~mA}$ ) analyses on 19 samples. Organic matter contents of 17 samples were obtained by using an oil show analyzer at the University of Paris 6, according to the method described by Espitalié et al. (1985a, 1985b, 1986). This technique gives a rapid determination of type and amount of organic matter (terrestrial versus marine) as well as its maturation and preservation state.

\section{Results}

\section{Biological and lithological composition}

\section{Facies}

The main common facies is unlithified floatstone in which coral fragments are the dominant bioclasts. The fragments are embedded in a matrix showing packstone or wackestone to mudstone fabrics (Fig. F3). In addition to the coral remains, other biologic components (bivalve and gastropod shells, echinoid spines, etc.) are present. The fine-grained fraction (from $10 \mu \mathrm{m}$ to $2 \mathrm{~mm}$ ) is composed of a mixture of carbonate and siliciclastic material (Figs. F3, F4). The mound sediments are often "unlithified" and appear dark and greenish gray (Fig. F3A). However, some "semi-lithified" horizons $<1 \mathrm{~m}$ thick occur and appear lighter in color (Fig. F3B). Typical burrow features are present in the semilithified horizons (Fig. F4A). Coral-free intervals $\sim 10 \mathrm{~cm}$ thick consisting of brown sandy to clayey silt are rarely observed. The mound base is a "firmground" corresponding to an erosional surface overlain by a basal mound succession of packstone containing coral debris. This basal facies is in contrast with the mound body where occurrence of large coldwater coral fragments appears within floatstone fabric (see the "Expedition 307 summary" chapter).

Four main facies types were coded during Expedition 307: floatstone, wackestone, rudstone, and packstone (Fig. F3). However, detailed microscopic investigation in this study reveals that the previous facies coding was related simply to the presence or absence of corals and the relative proportion of bioclasts and siliciclastic minerals (Fig. F3).

The floatstone facies consists of coral fragments and a greenish matrix of wackestone fabric (Fig. F3A). Macrofauna comprises essentially coldwater corals $(12.7 \%)$ and echinoid spines. The matrix is made of micrite (or microsparite) and microbioclasts $(<100 \mu \mathrm{m})$. Micrite forms $65.5 \%$ of sediment. The identified bioclasts are siliceous sponge spicules, echinoderms (Fig. F4D), bivalves, and planktonic (7.0\%) and benthic foraminifers and radiolarians. Glauconite is common (Figs. F3A, F4F) as well as framboidal pyrite (3.3\%) and silty quartz (10.3\%).

The wackestone facies consists of coral debris and a grayish matrix of wackestone to packstone fabrics (Fig. F3B). The matrix is composed of micrite (or microsparite) and silty quartz (15.6\%). Micrite forms $47.5 \%$ of sediment. Bioclasts are dominated by coral debris (16.3\%) and planktonic foraminifers (15.6\%) and include siliceous sponge spicules and radiolarians. Glauconite is present, and phosphate is frequent in the foraminifer chambers (Fig. F3B).

The rudstone facies consists of coral debris and a greenish to grayish matrix of wackestone fabric (Fig. F3C). The matrix consists of micrite or microsparite $(50.5 \%)$ and silty quartz $(21.8 \%)$. Bioclasts are dominated by coral debris (5.0\%) and planktonic foraminifers (18.8\%). Glauconite and framboidal pyrite are common (Fig. F4B, F4C) but their contents are $<4 \%$ of sediment (Fig. F3C).

The packstone facies consists of planktonic foraminifers and a grayish to greenish matrix of packstone to wackestone fabrics (Fig. F3D). The matrix is composed of micrite or microsparite $(67.0 \%)$ and silty quartz (20.2\%). A distinct feature of this facies is that it is devoid of coral debris. Bioclasts are dominated by planktonic foraminifers (16.5\%) and contain echinoderms and benthic foraminifers (Fig. F4E). Glauconite, framboidal pyrite, and phosphate (in the foraminifer loges) are common, but these authigenic minerals constitute $<6 \%$ of the sediment volume (Fig. F3D).

\section{Detailed matrix composition}

Results of our SEM and XRD investigations indicate that the matrix consists of two main fractions: biogenic and terrigenous (siliciclastic). The ratio between 
these two fractions likely reflects on the sediment color that records the cyclic change throughout the mound sequence (Ferdelman et al., 2006; see the "Expedition 307 summary" chapter).

\section{Biogenic fraction}

Calcareous nannofossils (Fig. F5) form the major part of the carbonate content of the mound sediment matrix. Besides the nannofossils, a large amount of fine-grained bioclasts is present, such as small coldwater coral debris, fragments of echinoderms, siliceous sponge spicules, radiolarians, planktonic and benthic foraminifers, gastropods, bivalves, and other unidentified biogenic fragments (Fig. F5). XRD analyses show the presence of calcite and aragonite in the matrix (Fig. F6). Aragonite likely derives from corals and to a lesser extent from mollusks. Pure calcite is mainly from nannofossils (coccolithophorids), whereas a limited amount of euhedral calcite is present (Fig. F7C).

\section{Terrigenous (siliciclastic) fraction}

Data from thin sections, SEM, and XRD analyses show that fine sands and silts are dominantly composed of quartz (from $10 \%$ to $20 \%$ of the whole sediment) (Figs. F4, F5, F7A). Clay minerals are abundant (from $10 \%$ to $50 \%$ of the mound sediment) and consist of the same association throughout the entire mound succession, comprising illite (37\%-45.6\%), kaolinite and chlorite (24\%-28.7\%), and smectite (1\%-10\%) (Fig. F6). Silt-sized grains of glauconite are also commonly observed (Figs. F3, F4B). The siliciclastic fraction has a very immature characteristic indicating detrital origin from nearby sources.

\section{Diagenetic fraction}

Framboidal and euhedral pyrite crystals are frequent and especially located within foraminifer chambers and perforations of corals (Fig. F7D). This pyrite probably has a diagenetic origin linked to bacterial sulfate reduction of organic matter and subsequent sulfide precipitation.

Phosphate precipitates are also common in some foraminifer chambers and intergranular spaces of the matrix.

\section{Coral bioerosion}

As mentioned above, the main producers of skeletal carbonate were coldwater corals. The coral fragments are ubiquitous throughout the mound. These fragments range from microscopic debris to branches $8 \mathrm{~cm}$ long, and all of them are randomly orientated in the matrix (Figs. F3, F4, F5, F7, F8). Most of the fragments, for which taxonomy was identified belong to the species L. pertusa. Many minor occurrences of Madrepora oculata and Desmophyllum cristagalli were noted (see the "Site U1317" chapter). The preservation of coral fragments and other large biogenic components is various throughout the mound succession. In some parts, coral fragments are partly pyritized or are associated with framboidal pyrite (Fig. F8B). Several corals show evidence of intense bioerosion (Fig. F8). Traces of fungi and sponges are quite common on the observed coral fragments. Large borings are attributed to clionid sponges (Fig. F8D).

Large tunnel-like borings from 5 to $10 \mathrm{~mm}$ in diameter (Fig. F8C) are identified as Orthogonum lineare (Glaub, 1994), whereas the round chambers are identified as Saccomorpha clava (Radtke, 1991). These traces are typical constituents and index ichnofossils for aphotic ichnocoenoses (Wisshak et al., 2005a, $2005 b)$. In conclusion, bioerosion is an important factor in weakening the coral skeletons and contributing to the production of carbonate grains. However, chemical aragonite dissolution occurred as well (dissolution cupules on aragonite crystals are recognizable) and enhanced the collapse of the coral frames.

\section{Organic matter content}

The results (Table T1) show that all 17 analyzed samples are low in total organic carbon (TOC) content (from $0 \%$ to $0.4 \%$; average $=0.2 \%$ ) (Fig. F9). The average value of the $T_{\max }$ parameter around $407^{\circ} \mathrm{C}$ (Fig. F9) indicates that the organic matter has not experienced strong thermal maturation. However, four samples (Samples 307-U1317A-5H-3, 85-90 cm; 10H-3, 85$90 \mathrm{~cm} ; 12 \mathrm{H}-3,75-80 \mathrm{~cm}$; and $14 \mathrm{H}-1,135-140 \mathrm{~cm}$ ) have a bimodal S2 pattern (Fig. F9), indicating that organic matter contains two fractions with different stability (maturity). One sample (307-U1317A-7H-1, $135-140 \mathrm{~cm}$ ) yields a higher $T_{\max }$ value of $455^{\circ} \mathrm{C}$, suggesting that this sample is abundant in mature organic particles (reworked from older rocks?).

Hydrogen index (HI) values are usually low $(<200 \mathrm{mg}$ hydrocarbon $[\mathrm{HC}] / \mathrm{g}$ TOC) indicating that the organic matter was highly oxidized and can be classified as Type IV (altered organic matter). Nevertheless, Sample 307-U1317A-10H-3, 85-90 cm, shows a high HI value (589 $\mathrm{mg} \mathrm{HC} / \mathrm{g}$ TOC) suggesting that the organic matter has a predominantly marine origin and can be classified as Type II (algae) or I (altered bacterial organic matter) (Espitalié et al., 1986).

\section{Conclusions}

Challenger Mound sediments are essentially composed of in situ biogenic components and allochthonous siliciclastic components. 
The biogenic components are dominated by coldwater coral fragments with a matrix composed of nannofossil (coccoliths) and fine-grained bioclasts (from $10 \mu \mathrm{m}$ to $2 \mathrm{~mm}$ in diameter), foraminifers, sponge spicules, radiolarians, echinoderms, bivalves, and gastropods. Coral fragments originated mainly from L. pertusa and to a lesser extent M. oculata and $D$. cristagalli. Coral fragments throughout the mound succession show traces of extensive dissolution, bioerosion, and fragmentation.

The siliciclastic components, mainly clay minerals (illite, kaolinite, and chlorite) and fine sand and siltsized quartz, are immature and allogenic.

Organic matter content is very low (average $=0.2 \%$ ). Its origin is difficult to determine because the organic matter is mostly oxidized and may be reworked. However, a bacterial origin seems unimportant.

\section{Acknowledgments}

We are grateful to the crew and technical staff of the JOIDES Resolution for their help as well as the scientists of Expedition 307. Samples and data were provided by the Integrated Ocean Drilling Program (IODP). This work has been financially supported by CNRS funding via the Laboratoire de Tectonophysique of Université de Montpellier 2. We thank Gilbert Camoin who introduced us to the IODP project. Thanks also to Lionel Marié for making the thin sections. The authors wish to thank the reviewers for comments that helped to improve the paper.

\section{References}

De Mol, B., 2002. Development of coral banks in Porcupine Seabight (SW Ireland): a multidisciplinary approach [Ph.D. dissert.]. Ghent Univ., Belgium.

De Mol, B., Van Rensbergen, P., Pillen, S., Van Herreweghe, K., Van Rooij, D., McDonnell, A., Huvenne, V., Ivanov, M., Swennen, R., and Henriet, J.P., 2002. Large deepwater coral banks in the Porcupine Basin, southwest of Ireland. Mar. Geol., 188(1-2):193-231. doi:10.1016/ S0025-3227(02)00281-5

Dunham, R.J., 1962. Classification of carbonate rocks according to depositional texture. In Ham, W.E. (Ed.), Classification of Carbonate Rocks. AAPG Mem., 1:108121.

Embry, A.F., and Klovan, J.E., 1971. A late Devonian reef tract on northeastern Banks Island, N.W.T. Bull. Can. Pet. Geol., 19(4):730-781.
Espitalié, J., Deroo, G., and Marquis, F., 1985a. La pyrolyse Rock-Eval et ses applications, Partie I. Rev. Inst. Fr. Pet., 40(5):563-579.

Espitalié, J., Deroo, G., and Marquis, F., 1985b. La pyrolyse Rock-Eval et ses applications, Partie II. Rev. Inst. Fr. Pet., 40(6):755-784.

Espitalié, J., Deroo, G., and Marquis, F., 1986. La pyrolyse Rock-Eval et ses applications, Partie III. Rev. Inst. Fr. Pet., 41:73-89.

Foubert, A., Beck, T., Wheeler, A.J., Opderbecke, J., Grehan, A., Klages, M., Thiede, J., Henriet, J.-P., and the Polarstern ARK-XIX/3A Shipboard Party, 2005. New view of the Belgica Mounds, Porcupine Seabight, NE Atlantic: preliminary results from the Polarstern ARK-XIX/3a ROV cruise. In Freiwald, A., and Roberts, J.M. (Eds.), Cold Water Corals and Ecosystems: Heidelberg (Springer-Verlag), 403-415.

Glaub, I., 1994. Microspores in selected deposits of the European Jurassic and the Lower Cretaceous: classification and paleontology. CFS, Cour. Forschungsinst. Senckenberg, 174.

Huvenne, V.A.I., De Mol, B., and Henriet, J.-P., 2003. A 3D seismic study of the morphology and spatial distribution of buried coral banks in the Porcupine Basin, southwest of Ireland. Mar. Geol., 198(1-2):5-25. doi:10.1016/S0025-3227(03)00092-6

Radtke, G., 1991. The microendolithic trace fossils in the lower Tertiary of Western Europe and their paleontological significance. CFS, Cour. Forschungsinst. Senckenberg, 138.

Van Rooij, D., De Mol, B., Huvenne, V., Ivanov, M., and Henriet, J.-P., 2003. Seismic evidence of current-controlled sedimentation in the Belgica mound province, upper Porcupine slope, southwest of Ireland. Mar. Geol., 195(1-4):31-53. doi:10.1016/S0025-3227(02)00681-3

Wisshak, M., Freiwald, A., Lundälv, T. and Gektidis, M., 2005a. The physical niche of the bathyal Lophelia pertusa in a nonbathyal setting: environmental controls and palaeoecological implications. In Freiwald, A. and Roberts, J.M. (Eds.), Cold-Water Corals and Ecosystems: Berlin (Springer-Verlag), 979-101.

Wisshak, M., Gektidis, M., Freiwald, A. and Lundälv, T., 2005 b. Bioerosion along a bathymetric gradient in coldtemperate setting (Kosterfjord, SW Sweden): an experimental study. Facies, 51(1-4):99-123. doi:10.1007/ s10347-005-0009-1

Initial Receipt: 13 June 2008

Acceptance: 26 November 2008

Publication: 14 April 2009

MS 307-204 
Figure F1. Bathymetric map of Porcupine Basin indicating drilling sites for Expedition 307 and high-resolution NNW-SSE seismic profile P000658 illustrating Challenger Mound (upper right). Modified from the "Expedition 307 summary" chapter.

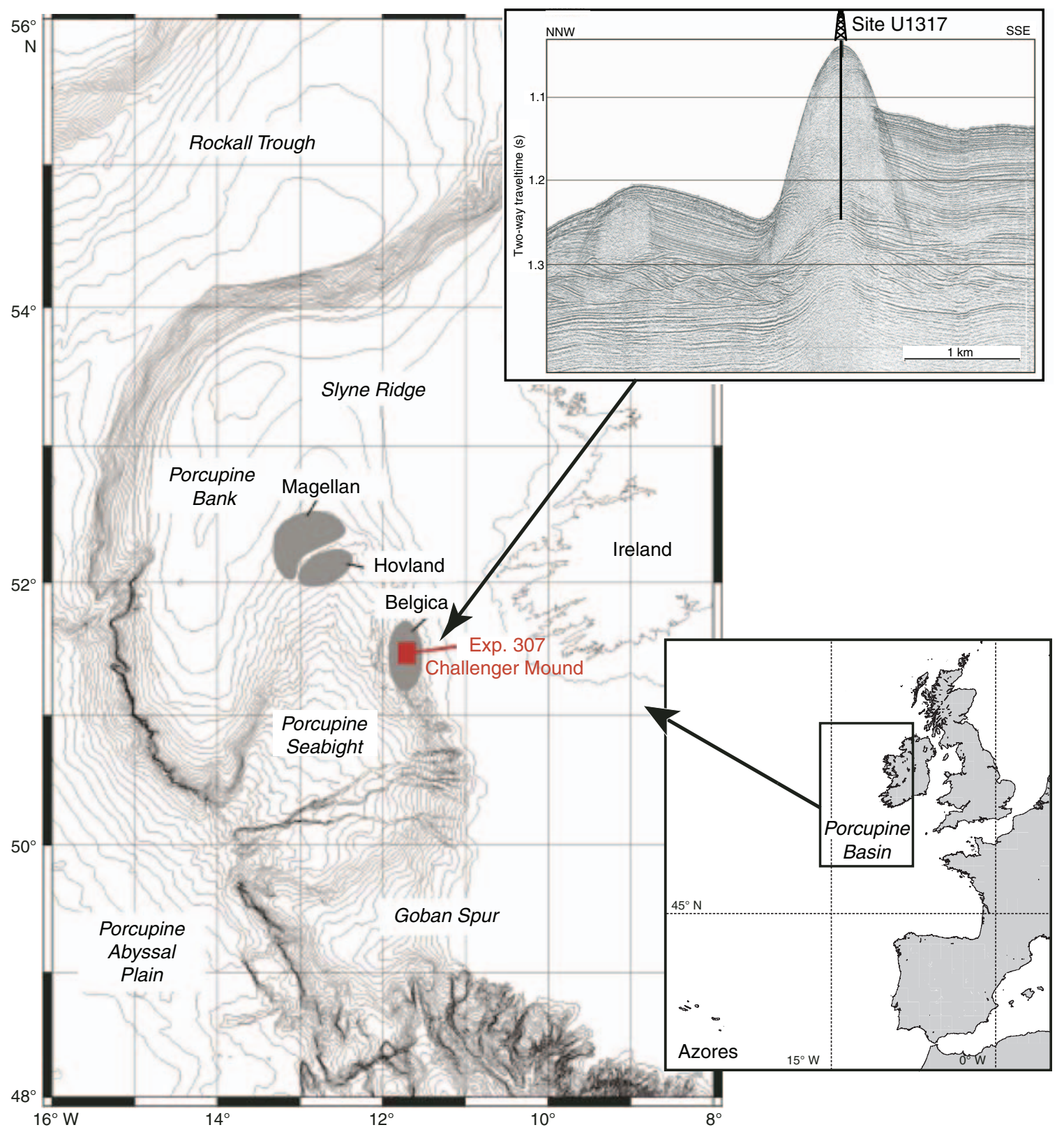


Figure F2. Lithostratigraphy of the three drilled sites projected on an interpreted seismic profile of Challenger Mound (modified from the "Expedition 307 summary" chapter; seismic interpretation from De Mol, 2002) and the columnar section of Hole U1317A showing sampling horizons.

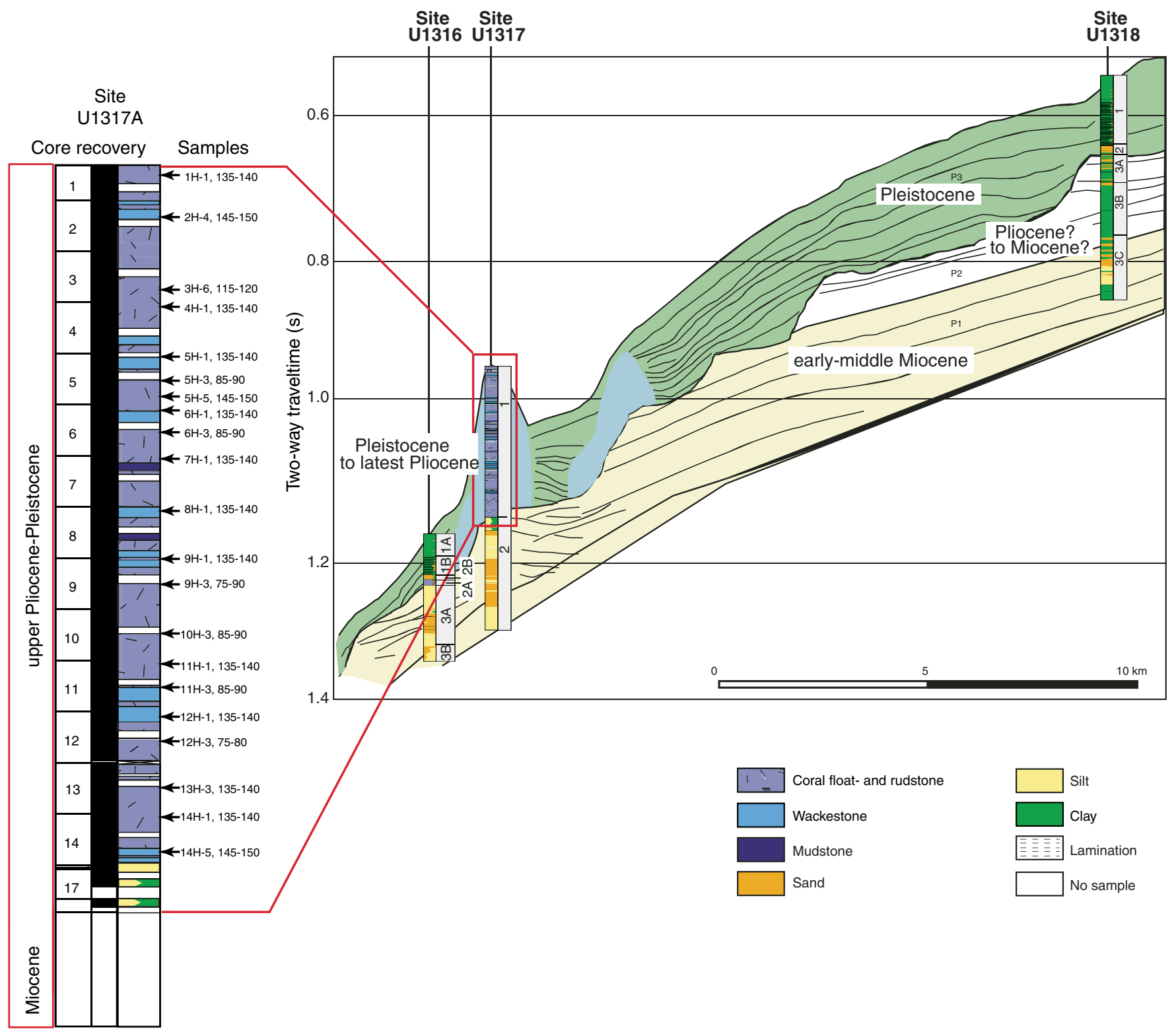


Figure F3. Four facies coded during Expedition 307 and their quantitative composition. A. Floatstone facies (Sample 307-U1317A-3H-6, 115-120 cm). White arrow = coral, black arrow = planktonic foraminifers. B. Wackestone facies (Sample 307-U1317A-1H-1, 135-140 cm). White arrow = quartz, black arrow = glauconite. C. Rudstone facies (Sample 307-1317A-2H-4, 145-150). Black arrow = coral debris. D. Packstone facies (Sample 307-U1317A-4H-1, 135-140 cm). Black arrow = planktonic foraminifers.
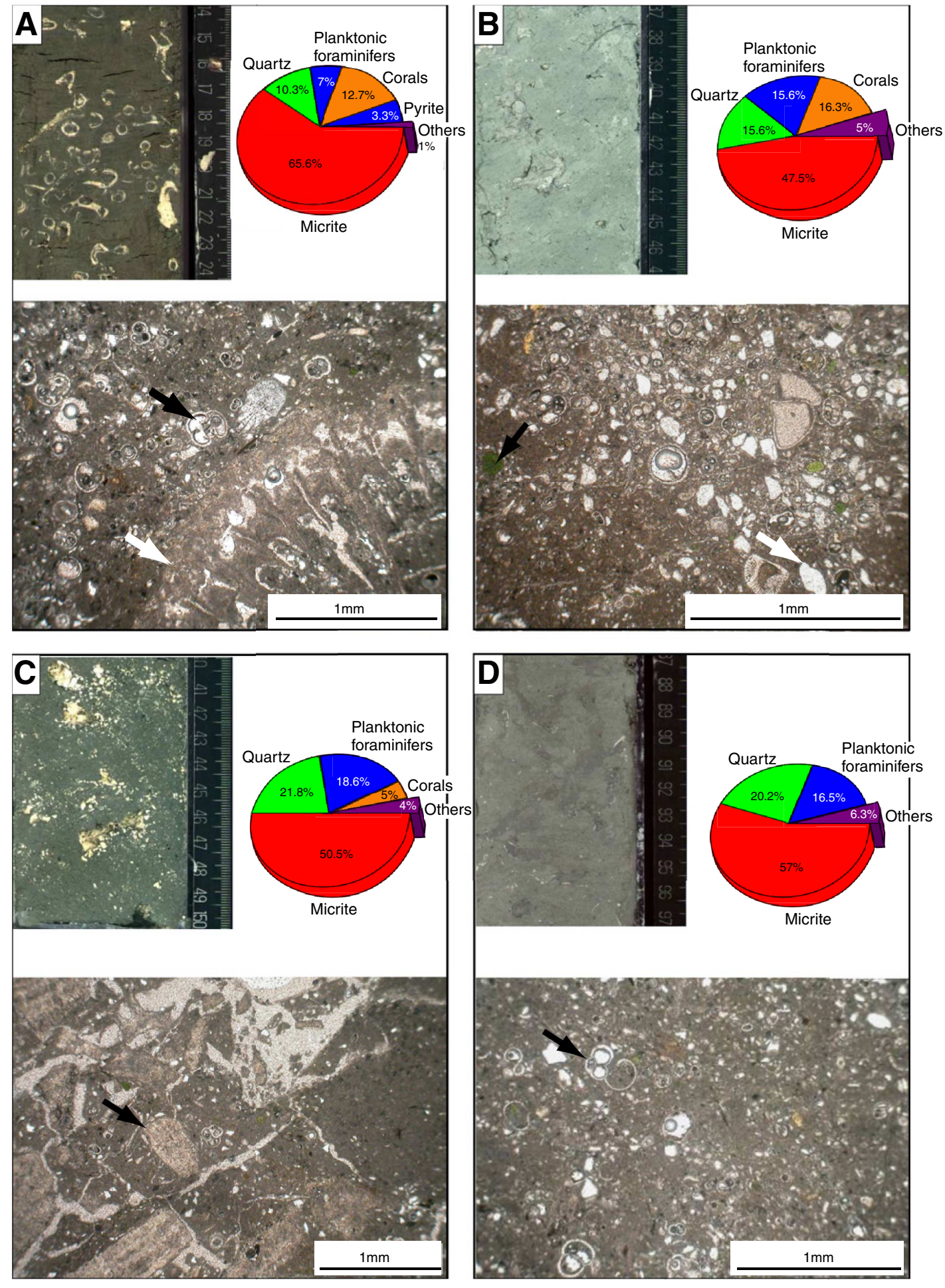
Figure F4. Microfacies of sediments from Challenger Mound. A. Bioturbation (white arrow) of quartzose wackestone (Sample 307-U1317A-12H-1, 135-140 cm). B. Quartz (black arrow), planktonic foraminifers, and glauconite (white arrow) (Sample 307-U1317A-1H-1, 135-140 cm). C. Planktonic foraminifers (white arrow) (Sample 307-U1317A-5H-5, 145-150 cm). D. Echinoid remain (white arrow) (Sample 307-U1317A-13H-3, 90-95 cm). E. Benthic foraminifers (black arrow) and echinoid spine (white arrow) (Sample 307-U1317A-4H-1, 135$140 \mathrm{~cm}$ ). F. Coral fragment (black arrow) and bioturbation (white arrow) in quartzose packstone abundant in planktonic foraminifers (Sample 307-U1317A-1H-1, 135-140 cm).
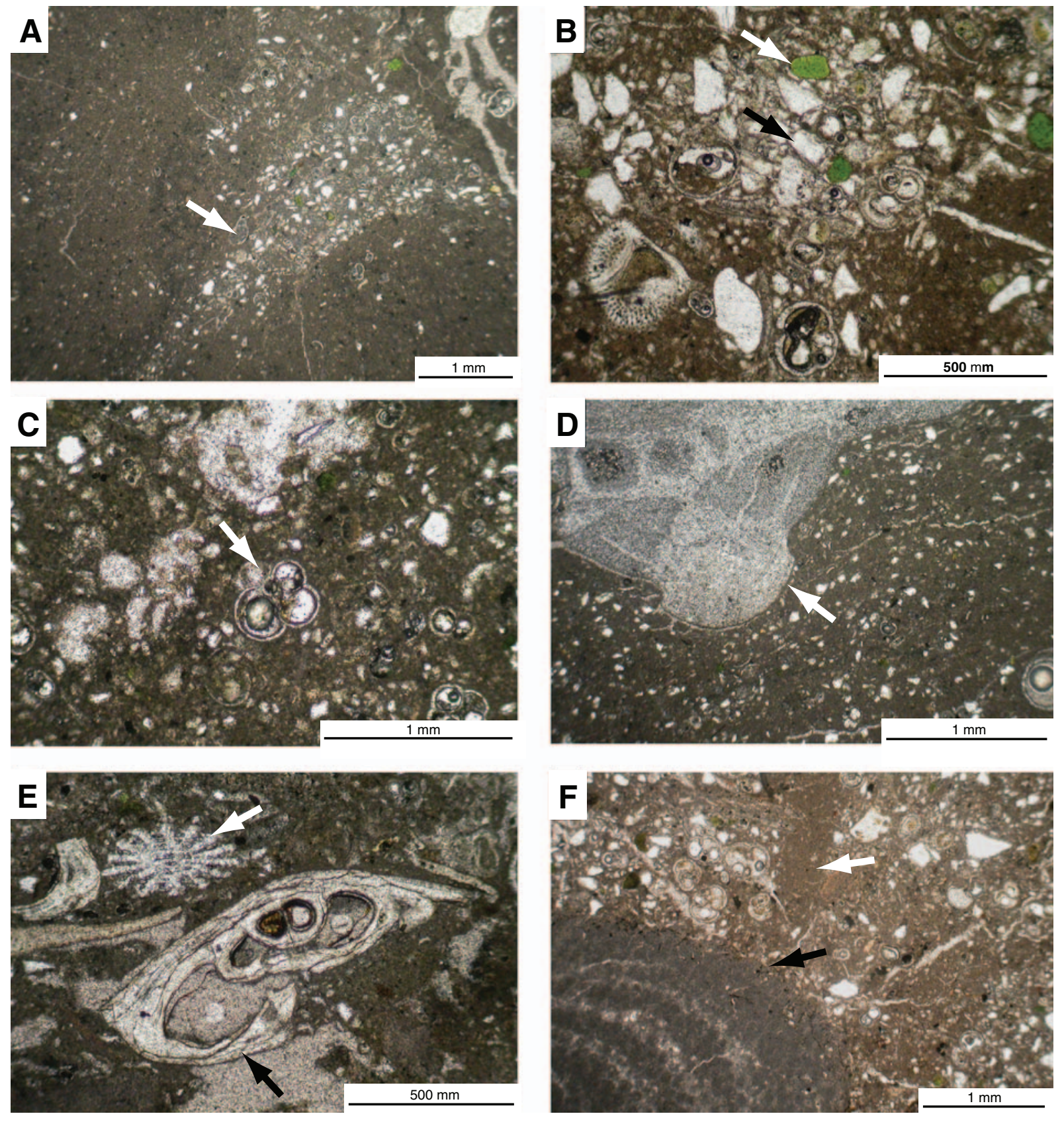
Figure F5. Scanning electron photomicrographs of bioclasts and minerals in mound sediments. A. Planktonic foraminifer (white arrow), radiolarian, and quartz (Sample 307-U1317A-8H-1, 135-140 cm). B. Benthic foraminifer (white arrow) (Sample 307-U1317A-8H-1, 135-140 cm). C. Coccolithophorids (white arrow) (Sample 307-U1317A-14H-5, 145-150 cm). D. Radiolarian (white arrow) (Sample 307-U1317A-8H-1, 135-140 cm). E. Echinoid spine (white arrow) (Sample 307-U1317A-2H-4, 145-150 cm). F. Sponge spicule (white arrow) (Sample 307-U1317A-8H-1, 135-140 cm).
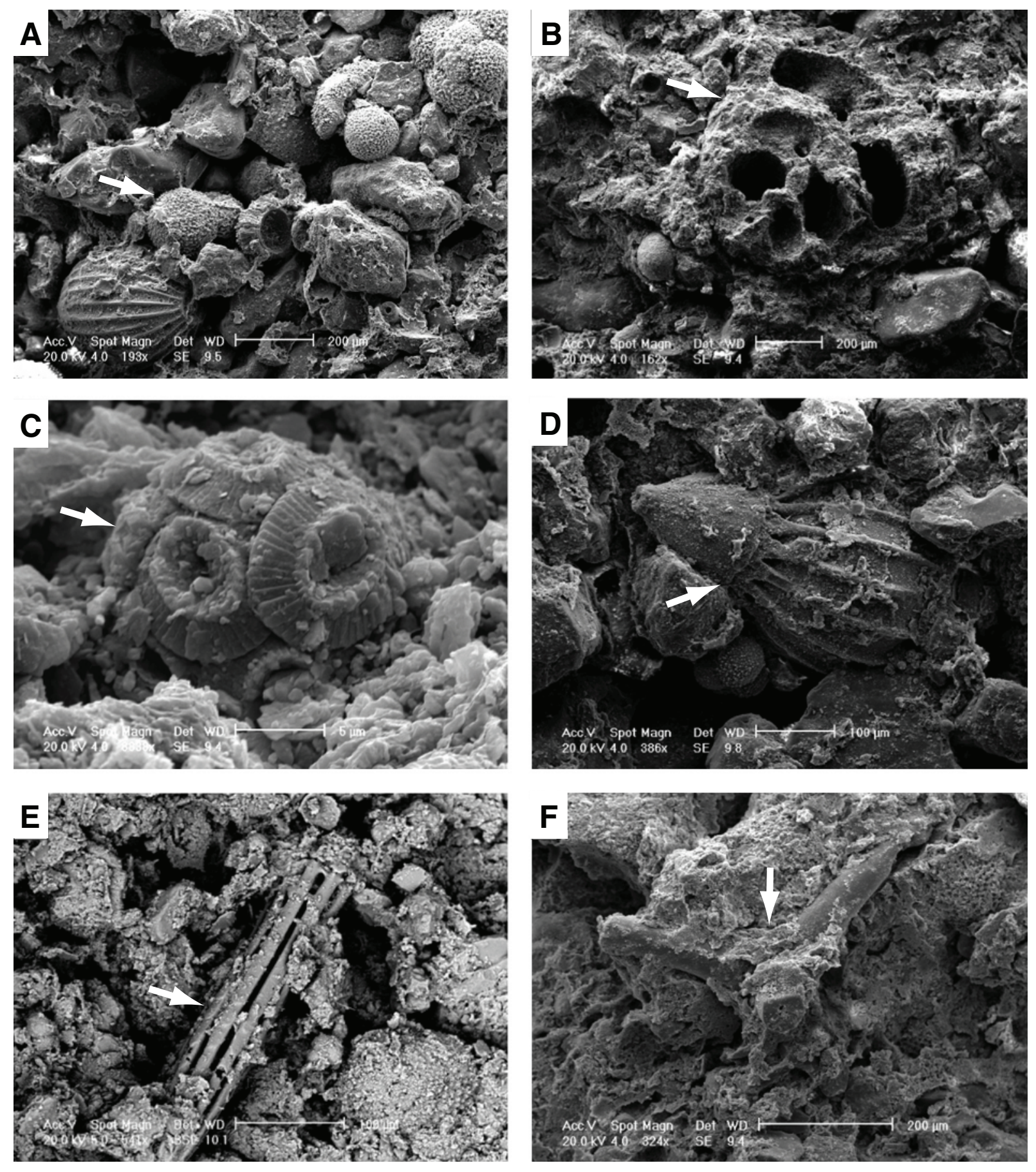
Figure F6. A. X-ray diffraction profiles of siliciclastic matrix showing the association of illite, kaolinite-chlorite, and smectite clay minerals (Sample 307-U1317A-5H-3, 85-90 cm). B. Representative energy dispersive X-ray spectrometry microanalysis values of the composition of the layered clay grain from Sample 307-U1317A-5H3, 85-90 cm (see Fig. F6B). C. Semiquantitative composition of clay minerals from six representative samples of Hole U1317A.

A
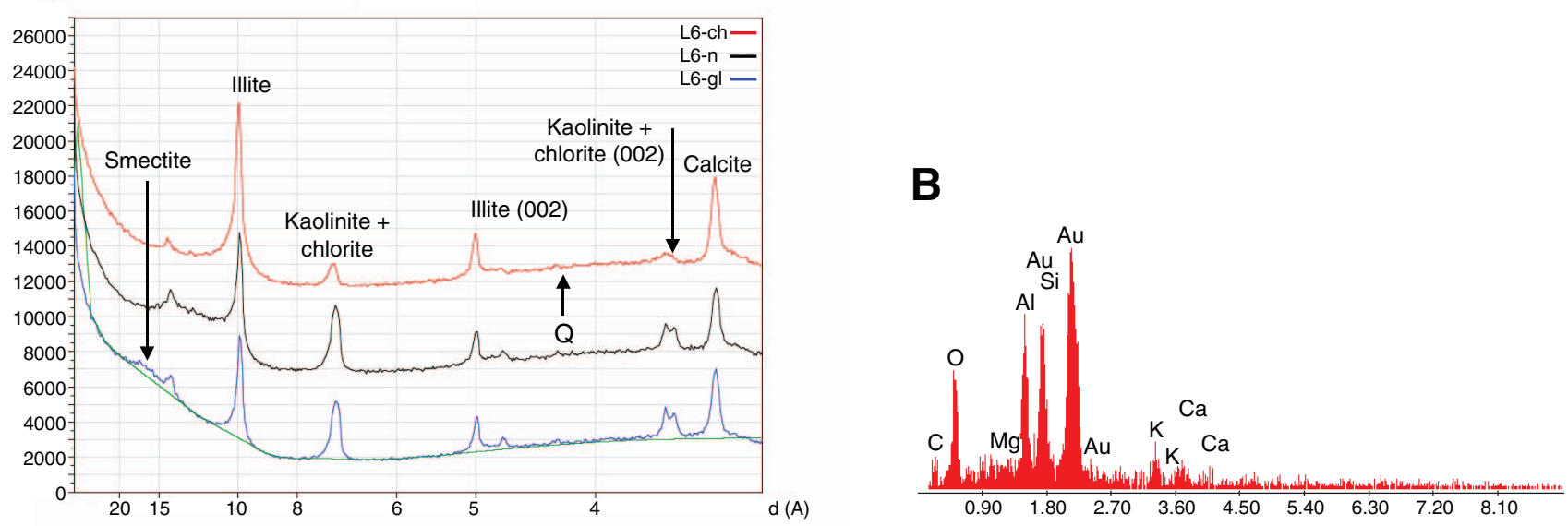

C

\begin{tabular}{l||}
\begin{tabular}{|c||c|c|c|c|c|c|}
\hline $307-U 1317 A$ \\
\hline Argil.ISamples & $4 \mathrm{H}-1,135-140 \mathrm{~cm}$ & $5 \mathrm{H}-1,135-140 \mathrm{~cm}$ & $5 \mathrm{H}-3,85-90 \mathrm{~cm}$ & $5 \mathrm{H}-5,145-150 \mathrm{~cm}$ & $9 \mathrm{H}-3,75-80 \mathrm{~cm}$ & $10 \mathrm{H}-3,85-90 \mathrm{~cm}$ \\
\hline \hline Smectite & $10 \%$ & $<1 \%$ & $2 \%$ & $<1 \%$ & $<4 \%$ & $7 \%$ \\
\hline Illite & $37 \%$ & $44 \%$ & $43 \%$ & $45.60 \%$ & $42 \%$ & $41 \%$ \\
\hline $\begin{array}{c}\text { Kaolinite\#+ } \\
\text { Chlorite }\end{array}$ & $24 \%$ & $28.70 \%$ & $26.40 \%$ & $28 \%$ & $24 \%$ & $27.50 \%$ \\
\hline Calcite & $28 \%$ & $27 \%$ & $28 \%$ & $26 \%$ & $30 \%$ & $24 \%$ \\
\hline $\begin{array}{c}\text { Other: } \\
\text { Quartz/Feldspar }\end{array}$ & $<1 \%$ & $<1 \%$ & $<1 \%$ & $<1 \%$ & $<1 \%$ & $<1 \%$ \\
\hline
\end{tabular}
\end{tabular}


Figure F7. Scanning electron photomicrographs of terrigenous and diagenetic fractions in mound sediments. A. Silt-sized quartz grain (white arrow) (Sample 307-U1317A-12H-1, 135-140 cm). B. Layered clay grain (white arrow) (Sample 307-U1317A-5H-3, 85-90 cm). C. Euhedral calcite crystals (white arrow) (Sample 307-U1317A8H-1, 135-140 cm). D. Pyrite in foraminifer chamber (white arrow) (Sample 307-U1317A-13H-3, 90-95 cm). E., F. Trioctahedral (euhedral) pyrite crystals (white arrow) (Sample 307-U1317A-14H-5, 145-150 cm).
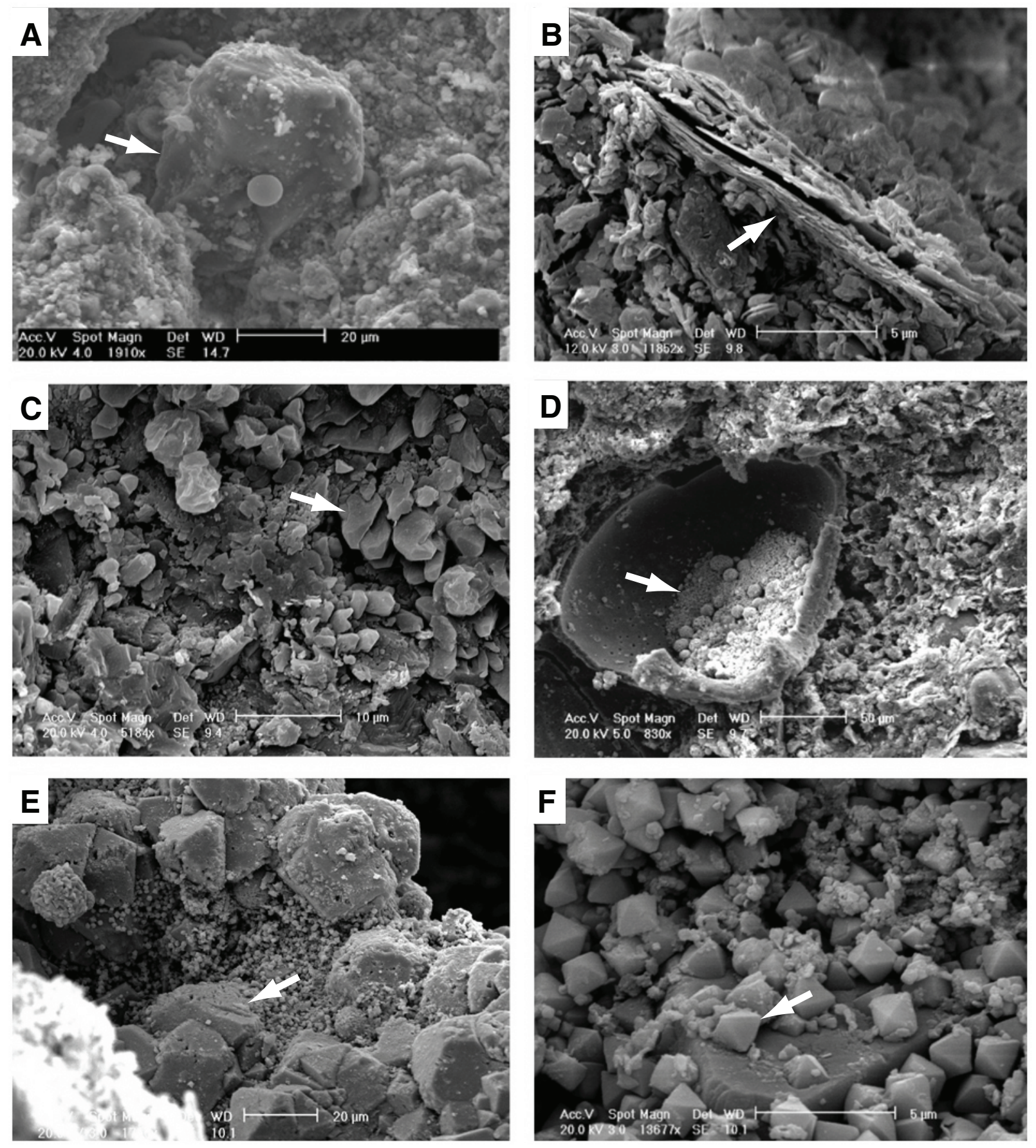
Figure F8. Scanning electron photomicrographs of corals and different traces of bioerosion on coral fragments. A. Aragonitic crystals of a coral skeleton (Sample 307-U1317A-8H-1, 135-140 cm). B. Rounded chambers of Saccomorpha clava (Radtke, 1991) (Sample 307-U1317A-3H-6, 115-120 cm) C. Tunnels $(5-10 \mu \mathrm{m}$ in diameter) of Orthogonum lineare (Glaub, 1994) (Sample 307-U1317A-5H-3, 85-90 cm). D. Large borings attributed to clionid sponges (Sample 307-U1317A-5H-5, 145-150 cm).
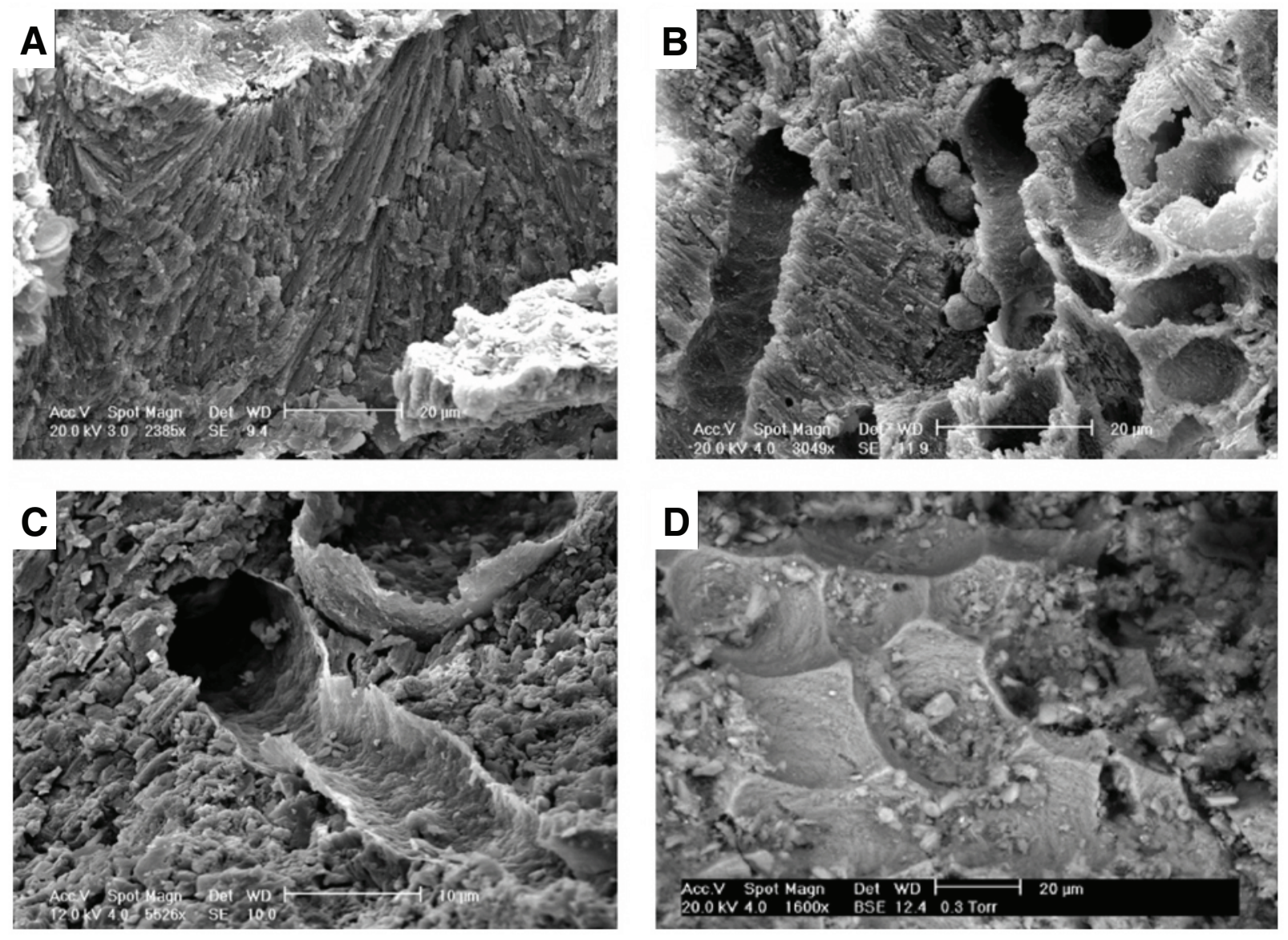
Figure F9. Organic matter content (TOC) and characteristics of organic matter ( $T_{\text {max }}, \mathrm{S} 1$ and S2 parameters, and hydrogen index [HI]) throughout Challenger Mound (Hole U1317) HC = hydrocarbon.
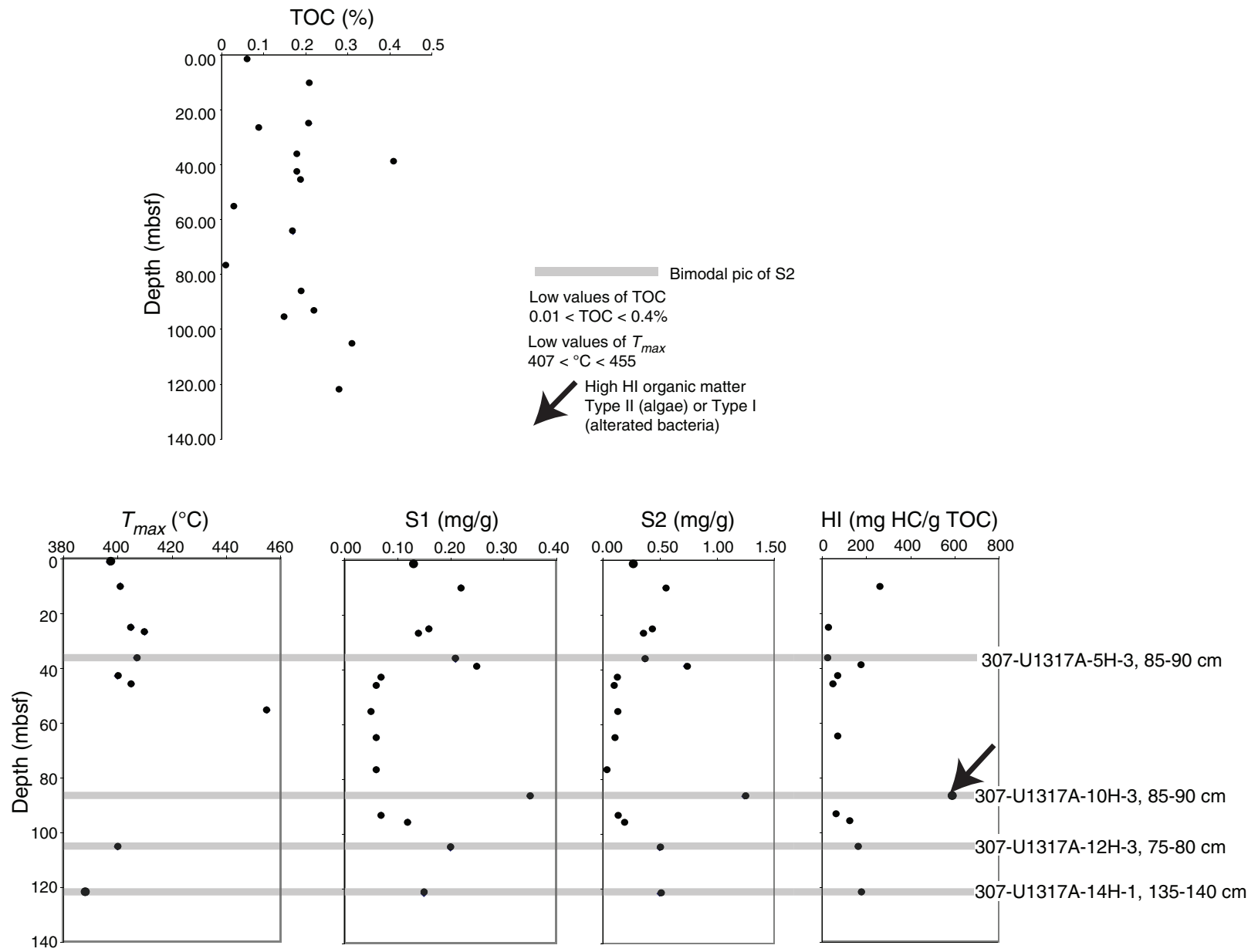
Table T1. Organic matter and carbonate content analyses results. (See table note.)

\begin{tabular}{|c|c|c|c|c|c|c|c|}
\hline $\begin{array}{l}\text { Core, section, } \\
\text { interval }(\mathrm{cm})\end{array}$ & $\begin{array}{l}\text { Depth } \\
\text { (mbsf) }\end{array}$ & $\begin{array}{l}T_{\max } \\
\left({ }^{\circ} \mathrm{C}\right)\end{array}$ & $\begin{array}{c}\mathrm{S} 1 \\
(\mathrm{mg} / \mathrm{g})\end{array}$ & $\begin{array}{c}\mathrm{S} 2 \\
(\mathrm{mg} / \mathrm{g})\end{array}$ & $\begin{array}{l}\text { TOC } \\
(\%)\end{array}$ & $\begin{array}{c}\mathrm{HI} \\
(\mathrm{mg} \mathrm{HC} / \mathrm{g} \text { TOC) }\end{array}$ & $\begin{array}{c}\mathrm{CaCO}_{3} \\
(\%)\end{array}$ \\
\hline \multicolumn{8}{|l|}{ 307-U1317A- } \\
\hline $1 \mathrm{H}-1,135-140$ & 1.35 & 397 & 0.13 & 0.26 & 0.06 & & 34.28 \\
\hline $2 \mathrm{H}-4,145-150$ & 10.20 & 401 & 0.22 & 0.55 & 0.21 & 261 & 53.81 \\
\hline $3 \mathrm{H}-6,115-120$ & 25.15 & 405 & 0.16 & 0.44 & 0.21 & 29 & 46.38 \\
\hline $4 \mathrm{H}-1,135-140$ & 26.85 & 410 & 0.14 & 0.35 & 0.09 & & 59.37 \\
\hline $5 \mathrm{H}-1,135-140$ & 36.35 & 407 & 0.21 & 0.37 & 0.18 & 25 & 63.52 \\
\hline $5 \mathrm{H}-3,85-90$ & 38.85 & & 0.25 & 0.73 & 0.41 & 178 & 60.4 \\
\hline $5 \mathrm{H}-5,145-150$ & 42.95 & 400 & 0.07 & 0.13 & 0.18 & 72 & 54.16 \\
\hline $6 \mathrm{H}-1,135-140$ & 45.85 & 405 & 0.06 & 0.1 & 0.19 & 52 & 67.01 \\
\hline $7 \mathrm{H}-1,75-80$ & 55.35 & 455 & 0.05 & 0.13 & 0.03 & & 68.89 \\
\hline $8 \mathrm{H}-1,135-140$ & 64.85 & & 0.06 & 0.1 & 0.17 & 58 & 47.77 \\
\hline $9 \mathrm{H}-3,135-140$ & 76.75 & & 0.06 & 0.04 & 0.01 & & 58.48 \\
\hline $10 \mathrm{H}-3,85-90$ & 86.35 & & 0.35 & 1.12 & 0.19 & 589 & 59.24 \\
\hline $11 \mathrm{H}-1,135-140$ & 93.35 & 400 & 0.07 & 0.14 & 0.22 & 63 & 20.78 \\
\hline $11 \mathrm{H}-3,85-90$ & 95.85 & 388 & 0.12 & 0.19 & 0.15 & 126 & 45.83 \\
\hline $12 \mathrm{H}-3,75-80$ & 105.25 & & 0.2 & 0.5 & 0.31 & 161 & 70.83 \\
\hline $14 \mathrm{H}-1,135-140$ & 121.85 & & 0.15 & 0.5 & 0.28 & 178 & 28.88 \\
\hline Average: & & 407 & 0.14 & 0.35 & 0.18 & 149 & \\
\hline Minimum: & & 388 & 0.05 & 0.04 & 0.01 & 25 & \\
\hline Maximum: & & 455 & 0.35 & 1.12 & 0.41 & 589 & \\
\hline
\end{tabular}

Note: $\mathrm{TOC}=$ total organic carbon, $\mathrm{HC}=$ hydrocarbon. 